\title{
Pitfalls of Decentralization Reforms in Transitional Societies: The Case of Uganda
}

\author{
William Muhumuza*
}

\begin{abstract}
Decentralization reforms are in essence necessary if they have genuine democratic objectives of empowering the people to make local-level governance efficient and effective. As the experience of Uganda reveals, donor-driven decentralization reforms have not performed according to expectations because of the converging external and domestic interests. This paper argues that for these reforms to succeed, the specific conditions pertaining to each country must be considered hand in hand with the honesty and political will of national leaders to genuinely transform power relations.
\end{abstract}

\section{Résumé}

Les réformes de la décentralisation sont essentiellement nécessaires si elles ont des objectifs réellement démocratiques de responsabilisation du peuple pour rendre la gouvernance locale efficace et efficiente. Comme le révèle l'expérience de l'Ouganda, les réformes de la décentralisation dictées par les bailleurs n’ont pas répondu aux attentes en raison des intérêts externes et internes convergents. Cet article défend l’idée que, pour que ces réformes puissent réussir, les conditions spécifiques propres à chaque pays doivent être prises en considération de pair avec l'honnêteté et la volonté politique des dirigeants nationaux de véritablement transformer les relations de pouvoir.

\section{Introduction}

Since the 1980s, decentralization has attracted worldwide support because of the assumed benefits that are associated with it. While decentralization reforms are heralded for promoting good governance and development, the real motives underlying its wide support have been given less attention.

* Department of Political Science, Makerere University, Uganda. 
The support given to decentralization reforms by donors is largely driven by ideological interests, such as the need to spread liberal values. On the other hand, African rulers embraced decentralization reforms not because they genuinely wanted to transform state-society relations but due to the need for political self-preservation. The economic and legitimacy crises that confronted the African state forced African rulers to accept public sector reforms as a precondition for the desperately needed aid. Therefore, the convergence of interests of Western donors and African rulers amply explain the support for decentralization reforms in Africa.

The practice of decentralizing power to sub-national levels of government is premised on the principle of subsidiarity whereby the power to tax, spend and regulate are exercised by lower levels of government (Beabout 1998). Thus, it is about giving autonomy in decision-making and accountability to the lowest possible level(s) of government. Decentralization is not a new practice. The global enthusiasm about decentralization experiments has simply intensified in the last two decades. Decentralization has been massively embraced in Africa owing to its troubled post-independence politics and economic woes. Although most African nationalist leaders campaigned for and attained independence on the basis of pluralist systems, these democratic experiments were short-lived. They were subsequently replaced with costly dirigiste approaches (Olowu 1989:204) that affected Africa's economic and political development prospects negatively.

By the late 1970s and early 1980s, Africa's economic and political ratings had nose-dived. Put differently, experimentation with centralization contributed to state collapse in Africa. The African state, which increasingly became characterized by predatory and neo-patrimonial governance (Sandbrook and Oelbaum 1997), became not only internally dysfunctional but also externally indebted. It is therefore in the wake of the failure of the centralized state in Africa that attempts were made by both the international community and local leaders to undertake reforms within the African state (Lancaster 1988:30). These comprised economic adjustment programmes and good governance reforms that aimed at bringing about a lean, democratic, efficient and effective state that could enhance development. Many African states that were previously afflicted by predatory and authoritarian tendencies have steadily embraced neo-liberal economic and political reforms. Decentralization is part of this reform process.

The delicate transition to economic and political change in Africa has attracted much debate. Uganda, being part of this transition, has been hailed internationally as a star performer, especially regarding the meticulous implementation of market-driven economic reforms (IMF 1995). While economic reform is considered successful, political reforms have been taken 
cautiously (Hauser 1999). Whereas much attention has been focused on Uganda's failure to consolidate multiparty political reforms, little or no attention has been paid to its decentralization reforms. This paper focuses on the effectiveness of decentralization reforms by examining the extent to which decentralization reforms have measured up to the proclaimed objectives of giving political, administrative and fiscal autonomy in decision-making to local authorities and consequently transforming the conditions of the people.

\section{Theoretical Context}

Donor-induced public sector reforms were premised on the neo-liberal perspective that attributes poor state performance in Africa to what Hyden (1980) termed the 'overdeveloped African State'. The notion of overdeveloped state implies that institutions such as government bureaucracy, the military, other specialized agencies and semi-autonomous marketing boards and parastatals became over-expanded. The overdeveloped state led to a waste of public resources, suffocated the private sector and reversed Africa's development prospects (Sandbrook 1985).

Public sector reforms included inter alia the restructuring of government through decentralizing power and functions to the lower levels of government. Decentralization, which is anchored to the philosophy of the neo-liberal perspective, has frequently been dubbed managerialism. According to Ingraham (1997:326), 'managerialism is based on private sector techniques and practices, which are amply leavened by public choice and market theories' (see Hughes 1994). Advocates of these reforms strongly believe that government should be managed like a business, with particular emphasis on efficiency and effectiveness. The overriding motive of the market-driven reforms is to create an efficient and effective public administration to support neo-liberal development policies (Russel and Nicholson 1981). More particularly, the market view of decentralization perceives local governments as producers of services while people are seen as consumers.

Therefore, the ongoing decentralization reforms must be conceptualized in this theoretical context. They are driven by the prime objective to have an efficient and effective government whose absence is considered to be an obstacle to the effective implementation and consolidation of market reforms. The implication of the market view is that the key objectives of decentralization can be achieved without necessarily pursuing wider and deeper democratic changes. This perception does not lead to genuine decentralization but to a pseudo form, which happens to be the mode that has been adopted by Yoweri Museveni's National Resistance Movement (NRM) government. GarciaGuadilla and Perez 2002:90), however, contend that true decentralization should entail the extension of democracy by transforming power relations. 
It transcends the strictly procedural democracy. Therefore, decentralization is about the transfer of real power vertically and horizontally, and enabling people to actively participate in decision-making in order to achieve social justice.

The advocates of decentralization associate it with various benefits. The most prevalent ones include the enhancement of democracy and development as well as strengthening accountability and legitimacy of government (Mawhood 1983). However, it ought to be noted that while these are strong theoretical justifications of decentralization and are indeed, very important, the real motives that underpin the acceptance to decentralize power in Africa are largely not well articulated and understood.

Support for decentralization by both the donor community and Africa's rulers has in most cases been driven by self-serving political interests as opposed to the genuine desire to empower the African people. Contrary to the usual rhetoric that decentralization is aimed at bringing people aboard, the reality on the ground is usually different. Decentralization is frequently used as a pretext to pursue centrally determined objectives. Likewise, donor support for decentralization reforms has been usually driven by ideological interests (Ingraham 1997:326; Hauser 1999:621-3). Since the nineteenth century, Western powers have been preoccupied with globalizing their values. These have historically ranged from the spread of cultural values to economic and political systems. Whereas the earlier period was characterized by the spread of cultural influence, the period during and after the Cold War has been marked by an attempt to globalize Western forms of democracy and economic systems. The focus has been on the adoption of classical neoliberalism, which mainly emphasizes multiparty political systems and marketdriven economic systems.

In Africa, these donor interests have been successfully pursued because of the inherent weaknesses of the African state. The lack of a clear ideological vision, mismanagement of the state and lack of strategic thinking by African rulers have increasingly exposed Africa to donor influence and dominance. Moreover, the fact that donor nations wield strong influence over the powerful international institutions such as the UN, World Bank and IMF, among others, allows them undue influence in shaping the global policy environment. Indeed, decentralization reforms constitute the 'new policy agenda', which puts special emphasis on markets, good governance and civil society. This agenda has been aggressively pursued by the World Bank and the donor community. Therefore, the decentralization reforms of the 1980s are aimed at providing institutional support to neo-liberal objectives of a lean and democratic state that is more accountable, efficient and effective (World Bank 1992; Young 1994). 
The underlying motive to embrace decentralization reforms by African rulers has been influenced by selfish political motives rather than the desire to promote local self-governance per se. African rulers accepted public sector reforms in general and decentralization in particular, not because they were convinced about the need for fundamental change, but for purposes of economic and political survival (Lancaster 1988:33). The economic collapse of most African nations climaxed in the late 1970s. The consequence of the state's failure to deliver social programmes made it irrelevant. Hence, the people became increasingly disengaged from the dysfunctional state and organized parallel institutions. This explains the growth of the informal sector in Africa, especially during the 1970s and 1980s. Given this sad situation, political desperation led African rulers to seek donor assistance, which came with the precondition to undertake certain reforms. Decentralization, being one of the reforms, was viewed by African rulers as a means to renew political legitimacy, especially in the countryside (Haruna 2001:47). Therefore, decentralization reforms should be viewed as a tactical weapon used by both external and internal actors to serve their selfish strategic interests. Thus, the African people became pawns in the chess game of good governance reforms that have remained a phantom. This game was nowhere more expertly played than in Museveni’s Uganda.

\section{Uganda and Decentralization Reforms}

The quest for decentralization in Uganda has in the last two decades attracted considerable attention and publicity. This phenomenon can be explained by changes in the international policy environment that strongly agitate for public sector reforms as a precondition for international assistance (Burki, Guillermo and Dillinger 19990. This should not, however, create an impression that decentralization is a recent occurrence in Uganda. Not only did some pre-colonial states of Uganda practise decentralization but also British colonialism decentralized power to local authorities (districts) immediately after the Second World War (Hicks 1961:104; Burke 1964). The famous Creech Jones dispatch of 1947 paved the way for the policy to decentralize power to Uganda's districts with effect from 1949. The period from 1949 onwards witnessed a number of democratic reforms in Uganda's local authorities up to the time of independence in 1962.

The independence government continued with the decentralized model of governance that had been inherited from its colonial predecessor. This was not because it cherished it, but because it was part of the formula that was agreed upon at the London constitutional conference between the British colonial government, political parties, kingdom ruling groups and district delegates before independence was granted (Mudoola 1993:23). The nationalist 
leaders agreed to this constitutional arrangement as a temporary measure. It was eventually abrogated in 1966; and with it, decentralization was also scrapped. The prospects of decentralization registered a complete decline in the 1970s and early 1980s as a result of the ensuing dictatorship and state collapse in the country.

It is not until the coming to power of the NRM government that efforts to decentralize power were revived. Decentralization constituted one of the policy reforms that were pursued by Yoweri Museveni's government immediately after ascending power. The NRM argued that decentralization was a component of the agenda to establish popular democracy in accordance with Point No. 1 of the Ten-Point Programme, a policy document prepared while still waging the protracted guerrilla war (1981-1985) (LGFC 1997:4). It was meant to guide the NRM government while in power. Indeed, the NRM's 'home-grown' policy to decentralize power seems to have come at a time when the international policy environment emphasized, among other things, decentralization reforms. Notwithstanding the NRM's rhetoric that the main motive for decentralizing power was to empower the grassroots democratically, available evidence does not corroborate this claim. The motive for NRM's policy to decentralize power was to acquire political legitimacy, since it had come to power through violent rather than democratic means (ICHRP 2002:6). Besides, decentralization was particularly attractive because it provided a suitable infrastructure to galvanize political support and reward loyalists. In short, the decentralization structure was a perfect tool for patronage politics. Accordingly, it has been effectively harnessed to serve the patronage objectives of the NRM government. It has been used to reward loyal cadres and, until recently, it has also served as a grassroots political structure for the NRM political organization (ROU 1997).

The official policy objective of decentralization indicates that it was to empower people, promote popular participation, equitable distribution of resources, accountability and responsibility while at the same time enhancing efficiency and effectiveness in service delivery (Wanyama 2002:2). In order to achieve these objectives, the NRM government embarked on an ambitious programme to implement decentralization. The initial process began in 1986 with the countrywide introduction of the Resistance Councils and Committees (RCs) system. This was a hierarchical five-tier structure of popularly elected councils and committees right from the village to the district level (Villadsen and Lubanga 1996:41-2). This was followed by the refinement of decentralization policy that was officially launched by President Museveni on 2 October 1992. Decentralization was progressively implemented through the enactment of supportive legislation from 1987 to 1997 . Not only was 
decentralization entrenched in the new Constitution of 1995, but also, the various legislations were subsequently harmonized under the Local Government Act of 1997.

The NRM government adopted the devolution form of decentralization, which gave local authorities substantial political, fiscal and administrative powers and responsibilities. Therefore, considerable autonomy was at least symbolically bestowed on local authorities while the line ministries retained the responsibilities for inspection, monitoring and coordination of local governments (ROU 1997:67-8). In addition to these central government responsibilities, there is the annual transfer of funds in the form of conditional, unconditional and equalization grants to local authorities. This is necessitated by the fact that local governments lack sufficient resources to execute their devolved responsibilities. Decentralization reforms have been implemented since 1993 and it is now well over a decade, a sufficient period to assess the extent to which change has been effected.

\section{A Critical Review of Decentralization Outcomes}

Advocates of decentralization widely believe that it is associated with socioeconomic and political benefits (WB 1998). More particularly, decentralization is assumed to enhance good governance, improve people's welfare and consequently bring about positive social change. Notwithstanding this idealistic romanticization of decentralization, critics highly doubt its ability to cause positive change. Indeed, available evidence suggests that despite various experiments with decentralization in Africa, limited progress has been achieved (Olowu 1990). It is within the context of these debates that this paper attempts to critically review the extent to which Uganda's decentralization reforms have performed.

One of the contentious areas has been the exaggerated multi-tier structure of local government. As earlier indicated, Uganda's local council (LC) system entails a five-tier hierarchical structure. Each tier has a council and committee. In addition to the elected committee members, the district, sub-county, city, municipality and town councils have elaborate administrative systems that are manned by appointed civil servants. Currently, Uganda has 80 rural districts, about 139 urban local governments and 958 sub-counties, which implies that many people are involved in decision-making at the local level. This situation paints such a rosy democratic picture. Indeed, Uganda has been lauded internationally for having successfully implemented decentralization that emphasizes bottom-up and gender-sensitive participation. ${ }^{1}$ Regarding the view that Uganda's multi-tier decentralized system enhances bottom-up participation that is gender-sensitive, the actual fact is that it is symbolically appealing but shallow in real terms. It is certain that the 
implementation of decentralization reforms expanded participation compared to the past when it used to be a privilege of certain elites in the national assembly. It is also true that Uganda's decentralization reforms expanded participation to sections of the population that were previously marginalized. For example, quotas for women, the youth and people with disabilities were entrenched in the law. It is a legal requirement that one-third of the local councils be constituted by women (ROU 1995:29-30; ROU 1997:15). While local government reforms have symbolically increased participation in terms of geographical space and numbers, the status quo has not changed much. Local governments have remained the preserve of local notables who have the education, financial resources and influence to contest for power. For example, the law stipulates that a candidate for a leadership position at the district level must have education qualifications of/or equivalent to an advanced level certificate while the leadership qualification for the sub-county level is the ordinary level certificate. Even at the village level, which is presumed to accommodate all grassroots people, leadership positions require literacy skills in reading and writing. This means that participation at this lowest rung is not necessarily all-inclusive as assumed. It is a preserve of the literate members of the community.

The implication of this to a country such as Uganda, where 76 per cent and 63 per cent of men and women are literate respectively (UBOS 2006:14), would be that many people participate and yet some people do not because of the widespread apathy concerning local councils. There are increasing reports that people shun council meetings, mobilization meetings and local elections, and avoid paying taxes. Few people attend council meetings at the village level because they are viewed as time-wasting since participation has not translated into improved government responsiveness and service delivery (Muhumuza 2006). Neither has popular participation influenced programme outcomes of local governments since local priorities are decided by the centre. As earlier pointed out, local government funding is in form of grants that are tied to priority areas that are centrally predetermined. The growing citizen apathy in local governments can be explained by the failure to link participation in council activities and payment of taxes to improved service delivery. Therefore, it is evident that participation ushered in by decentralization reforms is symbolic and not genuine.

It is also argued that instituting a quota for women to participate in local councils has not qualitatively changed their plight. This gives credence to the argument by Arnstein that there is a difference between going through the empty ritual of participation and having the real power to affect the outcome of the process (Arnstein 1971:176). Women councillors have neither advocated 
that women-specific issues be put on the agenda of local councils, nor have they mobilized, conscientized and organized the grassroots women so as to confront the forces that have historically oppressed them. This phenomenon corroborates the argument by Hart (1972:606) that democracy is not about how many times one participates but the importance of the decisions made. The reality is that this opportunity has benefited elite women who have pursued individual and selfish interests rather than those of grassroots women (Muhumuza 2004:25-40). Therefore, the argument that decentralization reforms have increased participation in Uganda needs to be treated with caution. Participation in Uganda's local governments has taken a ritualistic outlook and has not necessarily empowered the grassroots people to take full charge of their destiny.

While it is true that grassroots participation has been increased in symbolic terms, the main concern remains the cost. It is a well-known view that participation improves decision-making (Isham, Narayan and Pritchett 1995:175-200). However, the question is, should it involve everybody? Moreover, the proliferation of local government authorities has ended up consuming enormous financial resources that would otherwise be committed to development. Most of these local governments are small and unviable entities. Many of the new districts are not viable economically. They are created for patronage reasons as well as selfish political calculations to gain support, especially towards the period of presidential elections. For instance, in 2001, the year of a presidential election, the number of districts increased from 45 to 56 (Steffensen 2006:101) while in 2006, another election year, 13 more districts were created (ROU 2004:73; ROU 2007:20). What is more interesting is that these unite what used to be counties. Their creation has therefore overstretched already scarce financial and other resources. Although the fragmentation of local authorities is believed to be positively correlated with participation, it is costly for poor countries that need to commit their meagre resources to development. Besides, fragmentation leads to serious coordination problems. In the case of Uganda, fragmentation, which has increased the number of districts from 39 in 1993 to 80 in 2006, has not necessarily enhanced popular participation but has instead entrenched the power of elites.

Until recently, a big percentage of resources generated locally and contributions from the central government were used to meet recurrent costs of local governments. Large sums of money have been used to pay allowances and salaries for political leaders and technical staff in addition to other recurrent expenditure, as shown in Table 1. 


\section{Table 1: Uganda: Recurrent Expenditure 2001/02- 2005/06 (million shs)}

\begin{tabular}{|c|c|c|c|c|c|}
\hline Financial year (FY) & $2001 / 02$ & $2002 / 03$ & $2003 / 04$ & $2004 / 05$ & 2005/06 \\
\hline Public administration expenditure & 301,080 & 176,822 & 279,514 & 287,810 & 368,443 \\
\hline \multicolumn{6}{|l|}{$\begin{array}{l}\text { Public administration expenditure } \\
\text { as percentage of total government }\end{array}$} \\
\hline recurrent expenditure & $25.23 \%$ & $18.07 \%$ & $10.29 \%$ & $17.45 \%$ & $17.80 \%$ \\
\hline
\end{tabular}

Source: Republic of Uganda, Background to the Budget 2006/2007, Ministry of Finance, Planning and Economic Development, Kampala, June 2006.

Table 1 provides ample evidence that the cost of public administration consumes resources that would otherwise be used more productively for development. The cost of Uganda's public administration when compared to other sectors has been abnormally high. Whereas in the financial year 2001/2002 it was the highest (constituting 301080 million shillings or 25.23 per cent of the total recurrent expenditure), it consistently remained the third highest from financial year 2002/2003 to 2005/2006. The burden of a bloated local government structure has had to be shouldered by the central government since local authorities do not have sufficient resources to match the cost of devolved responsibilities. As a result of increasing costs of public administration, donors have repeatedly castigated the Uganda government (Wanyama 2002:13). It is therefore evident that Uganda's decentralization reforms have wasted scarce resources on public administration activities of local authorities (e.g. organizing periodic elections) instead of development.

It was earlier indicated that Uganda's decentralization reforms adopted a devolution form whereby political, administrative and fiscal autonomy was given to local authorities. The giving of fiscal autonomy to local authorities was indeed a step in the right direction. The major pitfall of decentralization experiments in Africa has been either the lack of power to generate revenue independently or because of a small resource envelope nationally. Whereas Uganda's local authorities are constitutionally empowered to raise revenue through local taxes, little progress has been made. First of all, revenue sources that were earmarked for local governments are unreliable, generate meagre resources and are administratively expensive to collect. The sources of revenue earmarked for local governments include fees, fines, cess, market dues, licences, ground rates and graduated personal tax (GPT), among others. These sources do not generate adequate revenue compared to the more lucrative and buoyant revenue sources that are exclusively retained by the central government such as VAT, PAYE, withholding tax, vehicle registration fees and excise duty, among many others. Correspondingly, the percentage 
of locally raised revenue has persistently declined to as low as 5 per cent of local government budgets. This has been partly attributed to political interference by the centre for purposes of gaining cheap political capital. For instance, GPT, which used to generate 70-80 per cent of all local revenue on average (Kiwanuka-Musisi 1999:14; ROU 2004:XVII), was politically decampaigned by Uganda's opposition candidate (Dr Kiiza Besigye) during the presidential elections of 2001 with promises to abolish it once elected. To avoid losing votes, President Museveni also promised to revisit it when elected. He later directed that low-income people pay a flat GPT of Ushs 3000 per annum. In order to avoid the risk of losing the 2006 elections, President Museveni had no choice but to completely abolish it with effect from 1 July 2005 (ROU 2007), only eight months from the general elections. The implication of this is that local governments have increasingly become dependent on the central government to fund their budgets. Rather than enhance the fiscal autonomy of local governments, the NRM government opted to retain the most lucrative taxable sources and instead transfer resources to local governments through grants.

Whereas it is usually argued that the central government's objective of using grants is to ensure income redistribution, it is strongly believed that the major driving factor is the quest for political control. Uganda's local governments are based on districts that historically have had strong ethnic allegiances. This phenomenon explains, to some extent, why the NRM government is slowly withdrawing some of the power initially given to local governments. The implementation of decentralization in Uganda once again aroused ethnic politics because elites manipulate them for purposes of political bargaining. As observed by Udogu (1999:791) political ethnicity remains one of the daunting obstacles to democratization in Africa. Hence, it may sometimes be necessary, as Uganda's case demonstrates, to limit the degree of decentralization for purposes of preserving national cohesion. Besides, where ethnic forces are strong and the state is still fragile, political leaders may find it irresistible to maintain some degree of political control when decentralizing to avoid state collapse. Therefore, for the sake of safeguarding national cohesion and exerting effective political control through patronage politics, the NRM government may have opted for more emphasis on grants. As a result of this financial control, local authorities have had to toe the central government's line.

Though Uganda's local governments appear to be autonomous with powers to make lawful decisions, plan, tax, budget and even enact by-laws, the reality is that in the absence of fiscal autonomy, these other powers cannot be adequately exercised. Since Uganda's local governments are 
dependent on central government grants for over 80 per cent of their total funding, their power of decision-making, planning and budgeting is highly curtailed. It is a fact that Uganda's local governments are actually implementers of central government priorities. This confirms the observation by Ali (1987:799), when referring to decentralization in Bangladesh, that in resourcepoor countries local governments may act as bureaucratic instruments of the centre rather than as generators of alternative values, performance and aspirations. This precarious situation has been exacerbated by the internationally driven poverty-reduction strategies whereby poor countries' policies and resources are redirected to specifically approved priority areas. In the case of Uganda, fiscal transfers from the centre have been increasing since 1993, as illustrated in Table 2.

\section{Table 2: Uganda: Fiscal Transfers to Local Governments, 1993/94-2002/03}

\begin{tabular}{lccc}
\hline $\begin{array}{l}\text { Financial } \\
\text { year (FY) }\end{array}$ & $\begin{array}{c}\text { Amount in billions } \\
\text { of Uganda shillings }\end{array}$ & $\begin{array}{l}\text { As a percentage of } \\
\text { the national recurrent }\end{array}$ & $\begin{array}{l}\text { As a percentage of } \\
\text { the recurrent budget and } \\
\text { development budget }\end{array}$ \\
\hline $1993 / 94$ & 31.5 & - & - \\
$1994 / 95$ & 70.2 & 8 & 17 \\
$1995 / 96$ & 116.6 & 12 & 25 \\
$1996 / 97$ & 176.5 & 14 & 30 \\
$1997 / 98$ & 196.4 & 14 & 30 \\
$1998 / 99$ & 282.3 & 17 & 34 \\
$1999 / 2000$ & 333.1 & 16 & 36 \\
$2000 / 01$ & 501.9 & 22 & 50 \\
$2001 / 02$ & 618.2 & 23 & 52 \\
$2002 / 03$ & 669.9 & 27 & \\
\hline
\end{tabular}

Source: Speech by the Minister of Local Government, 2003.

Table 2 confirms that total transfers to local governments from 1993/1994 (when the local government system was given a statutory basis) to 2002/ 2003, increased considerably from 31 billion Uganda shillings to 670 billion. Conditional grants constituted about 87.8 per cent of the total transfers. The increase in central government transfers can be explained by the fact that Uganda, as a beneficiary of debt relief, was required to target its expenditure on priority areas that would benefit the majority people and subsequently reduce poverty. Thus, the government policy to reduce poverty, namely, the Poverty Eradication Action Plan (PEAP) in 1997, identified five priority areas. 
These include universal primary education, primary health, water and sanitation, rural feeder roads, and agricultural modernization. The same national policy strategy guides the transfer of central government grants to local governments. For example, in FY 2006/2007, conditional grants accounted for 80 per cent of total transfers to local authorities (ROU 2007:28).

These priority areas are within the mandate of local governments, and therefore the central government had to increase fiscal transfers to ensure that these obligations are sufficiently funded. The Local Governments Act of 1997 gave local governments the responsibility for all field services that were previously managed by line ministries. Hence, local governments have a mandatory role in the delivery of the major public services identified as central to Uganda's poverty reduction strategy (Livingstone and Charlton 2001:79). However, the main problem with the various central government grants is that each specific grant has detailed conditions attached that must be fulfilled by the accounting officers of local authorities. This inevitably increases their workload. Moreover, the numerous conditions attached to grants overtax the energy of central government officials in the line ministries who have to ensure that all the districts comply with the conditions. The implication of this is that local governments just sit in their councils to rubberstamp the centrally derived policies. More importantly, anti-poverty transfers have promoted upward accountability, which is reminiscent of centralized government. This is a sad development that threatens the essence of devolution whose objective was to make government accountable to the people through a bottom-up process and not vice-versa (Craig and Porter 2003:62; Francis \& James 2003:330-3). Thence, local governments lack the autonomy to decide on their main priorities since they lack the financial means to implement them.

The inadequacy of local revenue sources has seriously frustrated the execution of locally identified priority programmes and the administrative activities of local governments. Local governments are supposed to use their internally generated revenues on wages, allowances, pensions, administrative costs and the implementation of development projects. However, central government interference such as the abolishing of GPT and roadside taxes on produce has seriously constrained the operations of local authorities. Not only have they failed to finance local development programmes that have been popularly decided through the participatory bottom-up planning process, ${ }^{2}$ but have also failed to pay salaries and wages to full-time district leaders, sitting and transport allowances to councillors as well as pay pensions to their retired employees. There are reports that councillors are increasingly shunning council meetings because of lack of funds to pay their allowances (ROU 2005:47). This has adversely affected the activities of councils. Besides, 
local government officials do not carry out their mobilization, consultation and supervisory activities regularly because of insufficient funds. Moreover, the plight of retired employees has become a big embarrassment to local authorities. This sorry state of affairs has prompted the central government's intervention to rescue local governments by promising to settle the pension arrears that had accumulated over four years to 17.5 billion shillings (ROU 2006:33).

As a result of inadequate funds, the central government had to take over the payment of salaries of full-time political leaders in local governments. These include the district local government chairpersons, vice chairpersons, speakers of council, executive secretaries, mayors and sub-county/division chairpersons. ${ }^{3}$ The move to take over the payment of salaries of top local government political leaders has attracted intense criticism since it undermines the essence of decentralization. These leaders are now viewed by the population as 'civil servants' and their power to make independent decisions is highly questionable. Put differently, they are perceived as compromised by the government.

More interesting is that the central government's takeover of the payment of salaries of full-time local government leaders originated from a presidential pledge during a meeting with them shortly before the first nationally organized multiparty election of 2006. The president had organized a meeting with the local government chiefs purportedly to listen to and discuss the problems and challenges that their local authorities were facing. The move was, however, interpreted as a disguised approach to solicit their political support in the 2006 multiparty elections. The local government leaders also opportunistically complained about poor remuneration, among many other issues discussed. Regardless of the centrality of other pressing issues raised in that meeting, the president placed special interest on their remuneration and immediately promised them a salary rise. The rise in their salaries was an irresistible move not only to win their political support during the upcoming elections but also to enable the central government to control them. Their salaries are now being paid from the consolidated fund (central government pool). However, there are central government plans to transfer back the payment of these salaries via unconditional grants.

The point to be emphasized here is that the failure of the central government to cede profitable and buoyant revenue sources to local governments has tremendously incapacitated local governments in executing their mandatory obligations. In short, inadequate revenues sources have made decentralization in Uganda a sham. Whereas the system design of Uganda's decentralization is impressive and if allowed to function properly would perhaps be quite effective, the reality on the ground is that Uganda's local governments have 
been greatly starved of independent resources and made dependent on the centre. Therefore, irrespective of the symbolic structures, officials and the bee-hive activities of local governments, the hidden face is that what glitters is not gold but disguised centralization at play.

The current status of decentralization reforms in Uganda is not accidental but is a product of well-calculated NRM strategy to manipulate donor conditions by creating an impression that power is decentralized when in actual fact it is not. The outcome of the political maneuvre has been successful because the NRM's agreement to 'decentralize' power improved its image abroad and allowed the smooth flow of donor aid. The act of decentralizing power to local authorities was carefully manipulated to the extent that it has been effectively used both as an instrument of patronage and political control at the grassroots (Smith 1985:194-7). It has therefore not served as an instrument for empowering the people to make popular and independent decisions, to plan, to make government responsive and to enforce accountability on a sustainable basis.

The euphoria about decentralization in Africa in particular was partly based on the expectation that popular participation would make local governments transparent and accountable compared to the remote and corrupt central government. This high expectation appears to have become an illusion in Uganda. Notwithstanding the massive but cosmetic participation in Uganda's local governments as exemplified by periodic elections, annual budget conferences organized with much fanfare, and a semblance of oversight institutions, poor accountability constitutes a big challenge. A number of official reports and stories in the mass media have repeatedly revealed the financial rot in local governments (e.g. ROU 2003:3; The New Vision, 31 January 2004:5; Sunday Monitor, 1 and 14-15 February 2004). Financial scandals that have either involved outright misappropriation of public resources or conniving to defraud or both by local officials have become rampant to the extent that in 2006 local governments were ranked the third most corrupt government institutions in Uganda (The New Vision, 4 January 2007:17). Likewise, the misuse of local government resources by officials has become common. More particularly, procurement of goods and services is characterized by corrupt tendencies where political leaders are reportedly involved in tender scandals that lead to conflicts of interest. Besides, rather than playing the role of supervising civil servants and also ensuring that taxpayers' money is put to good use, elected leaders instead connive with them and embezzle public resources. This confirms the argument by Treisman (2001:399-457; see also Bardhan \& Mookhejee 2000:135-9) that decentralization is likely to lead to capture by local interest groups and increased corruption. 
Other forms of corruption have been cited in the recruitment process. District officials have been reported to engage in acts that flout the standardized rules such as recruitment based on merit. They have been accused of promoting nepotism in recruitment. There has been a tendency to recruit people whose birth origins are from particular local governments while rejecting those from outside the district regardless of their suitability by qualification. There are also reports of influence-peddling in local government recruitment. Friends, relatives and political supporters of influential local government officials have been recruited fraudulently. A good example was in Rakai district where the government ombudsman (Inspector General of Government) had to intervene because of such irregularities that involved, among others, the district chairperson who influenced the recruitment of his son and daughter to the posts of Sub-county Chief and Environment Officer respectively (New Vision, 20 May 2007:3).

The growing corruption has negatively affected service delivery, which reaffirms the scepticism by Burki et al. (1999) that decentralization may also lower the quality of public services, as was the case in Latin America and Russia. Services have either been of poor quality or not available at all. This has increased people's disillusionment with local governments. Corruption has also intensified competition for leadership positions at the local government level compared to the past when individuals were reluctant to take on such leadership responsibilities because it was viewed as a sacrifice. This perception has greatly changed given the associated benefits. The competition for leadership positions in local governments has become so stiff that aspiring candidates are willing to spend considerable sums to bribe voters and buy out their opponents. In other circumstances, the contest for power has become violent and lives have been lost. A case in point was in Mayuge district where one of the contesting candidates for district chairperson was alleged to have been murdered by his competitor. All this is attributed to the material benefits that are closely associated with the positions of leadership in local governments.

In response to the growing corrupt tendencies, the NRM government has used it as a pretext to further weaken the autonomy of local governments. Not only has it recentralized the power to recruit and control key civil servants in local governments (with effect from 30 September 2005), but has also removed the political control over district procurement of goods and services from the elected leaders and transferred it to centrally controlled civil servants (ROU 2007:2-3). The tender boards, which used to be responsible for procurement, were scrapped and replaced by contract committees that are now composed of technical officers appointed by Chief Administrative 
Officers (CAOs) and Town Clerks. The recruitment of the CAOs and Town Clerks, who are accounting officers in the rural districts and urban local governments respectively, has also been recentralized. This means that Uganda's local governments have further lost the key personnel function to recruit and discipline their staff. This role serves an important function of ensuring that civil servants are loyal to people's representatives, who should ideally have effective political control over them. In the absence of this important personnel function, the autonomy of local governments is seriously eroded. The implication of the transfer of the CAOs and Town Clerks back to the centre would, according to Steffensen (2006:98), cut a crucial link of accountability between elected local councils and local government staff. Instead, central control has been reinforced and decentralization remains a mere shell.

Decentralization reforms are underpinned by the objective of freeing the central government from the unnecessary details of managing local level affairs. It was anticipated to free local authorities from central government interference so as to allow them flexibility and independence in decisionmaking to ensure innovation and sustainability. These intentions have been sacrificed for cheap and selfish political interests by the NRM leaders. Uganda's decentralization policy adopted RC popular structures that had initially been used by the NRM in the liberated parts of the country during the guerrilla war. The RC structure later functioned as a political organ of the NRM during the no-party period (1986-2005). It was eventually adopted as a local council structure, which was supposed to be separate from those organs of the NRM political organization. However, the NRM political organization has continued to treat the local council (LC) structure as one of its political organs to help it solicit political support at the grassroots especially during elections (ROU 1997). The president periodically invites local government delegations composed of locally elected leaders for meetings at his countryside home. As a consequence, many of them have ended up being co-opted and used to influence, mobilize support and campaign for the president.

The effect of this has not only compromised the autonomy of local governments but has also tarnished their image, given the fact that they are supposed to serve the interests of citizens regardless of their political inclinations. This situation has been worsened by the introduction of multiparty politics in 2005. The NRM which transformed into a political party, National Resistance Movement Organization (NRM-O), has continued to use the LC structure as its grassroots organ to galvanize political support for itself. There are allegations that the NRM party gave campaign funds for the 2006 
presidential elections to local council members to carry out the mobilization activities of the party.

The danger posed by the failure by the NRM party to distance itself from the LC structure came up more vividly during the re-election of district chairpersons for Kamuli and Pallisa districts in May 2007. In the case of Kamuli district, the opposition candidate for the Forum for Democratic Change (FDC) appeared likely to defeat the NRM candidate. However, the majority of elected councillors belonged to the NRM-O party. Subsequently, the Secretary General of the NRM-O party (Hon. Amama Mbabazi) and the president, who went there to promote the campaign of their candidate, discouraged voters from supporting the opposition candidate. They maintained that it would be a waste as the majority of councillors were NRM-O party members and would therefore make it difficult for a winning opposition candidate to form a government. Hence, the opposition chairperson would be unable to function. This argument is believed to have indirectly influenced the winning campaign of the NRM candidate. A similar situation transpired in the case of Pallisa where eventually the independent candidate won the election. However, the Secretary General of the NRM-O party wrote a letter to all NRM councillors of Pallisa district council who dominated it numerically (25 out of 37) not to accept nomination for positions in the district government headed by the new chairman unless he agreed to sign a memorandum of understanding to support the position of the NRM government (AmamaMbabazi 2007).

The patronizing approach that tends to characterize the multiparty political dispensation has equally contributed to the undermining of the principal objectives of decentralization reforms that stress autonomy in decision-making. Such practices may risk undermining local government legitimacy, especially among the people that subscribe to the opposition. Besides, there is a risk that future leaders who do not subscribe to the NRM party could dismantle the LC structure and replace it with a different system. This would negatively affect the process of building strong and enduring national institutions that are supposed to serve all the citizens irrespective of their diverging political affiliations.

\section{Conclusion}

There is no doubt that decentralization reforms are necessary, especially in African countries that tend to be associated with predatory and patrimonial politics. As earlier argued, the African state has passed through a series of economic and political crises that seriously eroded its competence and weakened its legitimacy. To address this crisis, the African state has had to be reorganized. Decentralization constitutes a component of public sector reforms 
that were pursued by African states. Restructuring power relations between the national and sub-national governments both vertically and horizontally is believed to promote good governance and sustainable development. It is because of these assumed advantages that decentralization reforms have attracted international support.

However, the experience with decentralization experiments in Africa is disappointing. The dismal performance of decentralization reforms on the continent needs to be understood within the context of the converging but self-serving interests of Western donors and African rulers. Whereas the motive of donors in advocating decentralization reforms is underpinned by ideological interests to spread their liberal values, African rulers accepted decentralization reforms for purposes of political preservation. In other words, decentralization reforms served two important purposes of accessing Western donor aid and creating political legitimacy. Therefore, Uganda's experience with decentralization reforms needs to be understood in the context of the converging selfish interests of Western donors and African rulers. The adoption of decentralization reforms by Museveni's NRM government was largely driven by the need to access Western aid and build grassroots patronage networks for his own political survival.

Therefore, the much-hyped decentralization reforms in Uganda have limitations because they were embraced as a matter of ritual rather than conviction per se. The consequence of this is that local governments' financial autonomy has been seriously weakened. Similarly, local council structures have been used to function as grassroots organs for the NRM-O party. Besides, decentralization reforms have not necessarily empowered the people in decision-making because of their capture by elites. They have also intensified corruption tendencies and consequently affected service delivery. Moreover, these reforms have ignited ethnic nationalism, as evidenced by nepotism in the recruitment of district employees. It is, however, important to recognize that the contradictions in question tend to take advantage of the weak capacity of the state. In normal circumstances, a strong state would find no problem reconciling such interests. Therefore, the main argument here is that rather than address the contradictions that arise from decentralization reforms, the NRM government has instead used them to justify its ulterior motives of recentralizing power.

It is evident that decentralization reforms are in essence good. However, they confront many challenges that are linked to state-building, especially in Africa. Ethnicity problems, insufficient financial resources and multiparty politics pose a big challenge to decentralization reforms in Africa, and therefore tend to discourage the centre from ceding more power. The interface of 
such challenges with the selfish political interests of major players tends to frustrate decentralization experiments. Therefore, decentralization reforms may not succeed unless the national state is itself reformed to allow internal democracy. This ought to be accompanied by honesty and political will on the side both of the Western advocates and African rulers. There must be a genuine need to transform power relations vertically and horizontally. Such reforms must be tailored to each country's specific realities. This implies that decentralization models should not be designed to 'fit all' irrespective of the diverse environmental circumstances. Hence, each nation must be allowed to adopt a model of reform that is compatible with its history, cultural values and political realities.

\section{Notes}

1. In order to reverse the age-old discrimination of women, the law stipulates that women must constitute a third of all local councils in Uganda.

2. The participatory bottom-up planning process is the mandatory mode of planning in all local governments of Uganda.

3. The law that governs Uganda's local governments (Local Governments Act, 1997) stipulates that the number of secretaries/ministers must not exceed a maximum of five.

\section{References}

Ali, Shawakat, A. M. M., 1987, Decentralization for Development: Experiment in Local Government Administration in Bangladesh, Asian Survey 27(7): 787799.

Arnstein, S. R., 1971, A Ladder of Participation in the U.S.A., Journal of the Royal Town Planning Institute, April: 176-182.

Bardhan, P. and Mookhejee, D., 2000, Capture and Governance at Local and National Levels, American Economic Review 90(2): 135-139.

Beabout, G. R., 1998, The Principle of Subsidiarity and Freedom in the Family,

Church, Market and Government, Markets and Morality 1(2), October. Accessed at: ttp://www.acton.org/publicat/m_and_m/1998_oct/beabout.html Burke, F., 1964, Local Government and Politics in Uganda, Syracuse and New York: Syracuse University Press.

Burki, S. J., Perry, G. E. and Dellinger, W., 1999, Beyond the Center: Decentralizing the state, Washington, D.C.: World Bank.

Craig, D. and Porter, D., 2003, Poverty Reduction Strategy Papers: A New Convergence, World Development 31(1): 53-69.

Francis, P. and James, R., 2003, Balancing Rural Poverty Reduction and Citizen Participation: The Contradiction of Uganda's Decentralization Programme, World Development 31(2): 325-337. 
Garcia-Guadilla, M. P. and Perez, C., 2002, Democracy, Decentralization and Clientilism: New Relationships and old Practices, Latin American Perspectives 29(5): 90-109.

Hart, D. K., 1972, Theories of Government Related to Decentralization and Citizen Participation, Public Administration Review 32: 603-621.

Haruna, F. P., 2001, Reflective Public Administration Reform: Building Relationships, Bridging Gaps in Ghana, African Studies Review 44(1): 37-57.

Hauser, E., 1999, Uganda Relations with Western Donors in the 1990s: What Impact on Democratization?, The Journal of Modern African Studies 37(4): 621-641.

Hicks, U. K., 1961, Development From Below: Local Government and Finance in Developing Countries of the Commonwealth, Oxford: Clarendon Press.

Hughes, O. E., 1994, Public Management and Administration, New York: St Martin's Press.

Hyden, G., 1980, Beyond Ujamaa in Tanzania, Berkeley: University of California Press.

International Monetary Fund (IMF), 1995, Uganda: Back from the Brink and on the Path to Sustained Growth, IMF Survey 24(22), 11 December.

Ingraham, P. W., 1997, 'Play it Again, Sam; It's Still Not Right': Searching for the Right Notes in Administrative Reform, Public Administration Review 57(4): 325-331.

International Council of Human Rights Policy (ICHRP), 2002, Local Rule: Decentralization and Human Rights, Versoix: ICHRP.

Isham, I., Narayan, D. and Pritchett, L., 1995, Does Participation Improve Performance? Establishing Causality with Subjective Data, The World Bank Economic Review 9(2): 175-200.

Kiwanuka-Musisi, C. G., 1999, 'Emerging Issues in the Implementation of Decentralization', Paper presented at the National Forum on the Implementation of Decentralization in Uganda, 18 November.

Lancaster, C., 1988, Policy Reform in Africa: How Effective?, A Journal of Opinion 16(2): 30-35.

Livingstone, I. and Charlton, R., 2001, 'Financing Decentralized Development in a Low-income Country: Raising Revenue for Local Government in Uganda', Development and Change 32(1): 77-100.

Local Government Finance Commission, 1997, Financial Decentralization in Uganda, Commission Report No. 1(February 1995-December 1996), Kampala: LGFC.

Manor, J., 1998, The Political Economy of Democratic Decentralization, Washington, D.C.: World Bank.

Mawhood, P. (ed.), 1983, Local Government in the Third World: The Experience in Tropical Africa, Chichester: John Wiley.

Mbabazi, Amama, 2007, Political Situation in Pallisa District after the ByeElection for LC5 Chairperson, Kampala: Office of the Secretary General, National Resistance Movement, 17 May. 
Mudoola, D. M., 1993, Religion, Ethnicity and Politics in Uganda, Kampala: Fountain Publishers.

Muhumuza, W., 2004, The Empowerment of Women in Museveni’s Uganda: Who Benefits?, The Australasian Review of African Studies 26(2): 25-40.

Muhumuza, W., 2006, Decentralization and State Rebuilding in Uganda, Research Report, Kampala: SIDA/SAREC and FSS, Makerere University.

Olowu, D., 1989, Local Institutions and Development: The African Experience,

Canadian Journal of African Studies 23(2): 201-231.

Olowu, D., 1990, The Failure of Current Decentralization Programmes in Africa, in

Wunsch, J. and Olowu, D., The Failure of the Centralized State, Boulder, CO:

Westview Press.

Republic of Uganda (ROU), 1995, Constitution of the Republic of Uganda, Entebbe: UPPC.

Republic of Uganda (ROU), 1997, The Local Governments Act, 1997, Entebbe: UPPC.

Republic of Uganda (ROU), 1997, The Movement Act, 1997, S 25, Entebbe: UPPC. Republic of Uganda (ROU), 2003, Decentralization and Modernization of Uganda:

A Challenge to Local Governance, a Speech by the Minister of Local Government while visiting Iganga District, Kampala: Ministry of Local Government.

Republic of Uganda (ROU), 2004, Annual Report to Parliament, 2004, Kampala:

Local Government Finance Commission.

Republic of Uganda (ROU), 2005, Annual Assessment of Minimum Conditions and Performance Measures for Local Government, 2004, Kampala: Ministry of Local Government.

Republic of Uganda (ROU), 2006, Background to the Budget 2006/2007, Kampala:

Ministry of Finance, Planning and Economic Development.

Republic of Uganda (ROU), 2006, Ministerial Policy Statement for Financial Year 2006/2007, Kampala: Ministry of Local Government.

Republic of Uganda (ROU), 2006, Uganda National Household Survey 2005/

2006, Report on the Socio-Economic Module, Kampala: Uganda Bureau of Statistics.

Russel, C. S. and Nicholson, N.K. (eds), 1981, Public Choice and Rural

Development, Washington, D. C.: Resources for the Future.

Sandbrook, R., 1985, The Politics of Africa's Economic Stagnation, Cambridge:

Cambridge University Press.

Sandbrook, R. and Oelbaum, J., 1997, Reforming Dysfunctional Institutions through

Democratization? Reflections on Ghana, The Journal of Modern African

Studies 35(4): 603-646.

Smith, Brian C., 1985, Decentralization: The Territorial Dimension of the State, London: Allen \& Unwin.

Steffensen, J., 2006, Local Government Organization and Finance: Uganda, in

Anwar, S. (ed.), Local Governance in Developing Countries, Washington,

D.C.: World Bank, pp. 93-136. 
Sunday Monitor, 2004, How Decentralization Took Corruption to Districts, 1 February.

The New Vision, 2004, IGG Says Trim Local Government Powers, 31 January. The New Vision, 2007, Local Government: Third Most Corrupt Institution, by Mikaili Sseppuya, 4 January.

The New Vision, 2007, Inspectorate of Government Probes Nepotism in Rakai, by Dismus Buregyeya, 20 May.

Treisman, D., 2001, The Causes of Corruption: A Cross-national Study, Journal of Public Economics 76(3): 399-457.

Udogu, I._E., 1999, The Issue of Ethnicity and Democratization in Africa: Toward the Millenium, Journal of Black Studies 29(6): 790-808.

Villadsen, S. and Lubanga, F. (eds), 1996, Democratic Decentralization in Uganda: A New Approach to Local Governance, Kampala: Fountain Publishers.

Wanyama, R., 2002, Donor News 2(2): 1-17 (July-September).

World Bank (WB), 1992, Governance and Development, Washington, D.C.: World Bank.

World Bank (WB), 1998, Rethinking Decentralization in Developing Countries, Washington, D.C.: World Bank.

Young, T., 1994, Governance, the World Bank and Liberal Theory, Political Studies 42(1): 84-100. 
